\title{
STUDENTS' CAREER EDUCATION IN GENERAL EDUCATION SCHOOLS: PRACTICAL IMPLEMENTATION, PROBLEMS AND IMPROVEMENT POSSIBILITIES
}

\author{
Kristina Gelažauskienè \\ Klaipėda Pedagogical Psychological Service, Lithuania \\ E-mail: kgelazauskiene@gmail.com \\ Dalia Augienè, Vincentas Lamanauskas \\ Šiauliai University, Lithuania \\ E-mail: augiene@gmail.com, v.lamanauskas@ef.su.It
}

\begin{abstract}
School has to guarantee the effective development of career competencies, which are necessary to consciously and successfully create and manage your career and, respecting student's inclinations, values and abilities, to help him cognise himself, the activity world, and to choose future career. It is important to make conditions for all students to develop their career competencies, to support them in the process of cognising, creating and realising themselves. Career education is a common team work, the success of which is possible if most of the school employees contribute to career competence development, various school activities, oriented to students' personality maturity help students as well to acquire and develop the competencies necessary for successful career.

In the research, it was referred to an attitude that career education is a systematic and purposeful process, by which it is helped the student to make a career choice and to acquire career competencies. The research object was - career education in general education schools. The research aim was - to ascertain teachers' attitude to career education in general education schools. In the research, a survey strategy was applied. Descriptive statistics procedure was applied for calculation of frequencies and comparing of averages. It was a pilot research. The research took place in Klaipeda city municipality general education schools in 2017. In the research, the teachers from 100 general education schools took part. The survey was carried out online. Using "Google forms" device, the questionnaire was presented to school teachers.

The research results revealed that education process was very intensive, there was a lack of time for carrying out career education activities, lack of consistency, financing, not in all schools career education programme was prepared, there was lack of efficiency, there were not enough career education programmes, methodological devices, there was lack of all school community involvement in career education organisation and social partner help for career education activity implementation outside the school. Research results showed that carrying out career education activities was problematic.
\end{abstract}

Keywords: career education, career choice, career competencies, general education school. 


\section{Introduction}

Lithuanian economy restructuring taking place and its integration into European union economic structures, human resource quality becomes very important, which is determined by education and vocational teaching level and labour market interaction. According to Pukelis and Garniene (2003), the main indicator of this quality is an appropriate career choice and ability to plan one's career. The research showed that the efficient career development is dependent on individual career planning and career management (Chetana \& Das Mohapatra, 2017).

In the present social and economic transformation period, career choice becomes not a onetime decision act for the whole life, but a constant process. The character of this phenomenon changes - from one-time it becomes a continuous process (Pukelis, 2003). Before choosing a profession, a person must analyse a lot of possibilities, has to make a lot of partial decisions. Career education becomes a significant part of general education, the educational influence of which remains important on the learners throughout the life. This conception is defined as a systematic and purposeful process, by which it is helped the student to make a career choice and to acquire career competencies.

The main career education aim is - to help students make a career choice, corresponding as much as possible to their personality and demands, i.e., to make the best possible career decision. During it, a particular role has to be performed - it is helped the students coordinate ambitions and possibilities, adapt them to constantly changing society social and economic demands. According to Surgèlienè and Bankauskienè (2014), a life career conception becomes more urgent, emphasising not only a professional person's activity sphere, but also all his life's success. According to the mentioned authors, the emergence of new professions, vast available information flows raise sufficiently big difficulties for general education school students making career decisions. They encounter the challenge of choosing such a career, which would help to implement personal desires and inclinations, conform to abilities, and would also correspond to economic situation. Due to this, the demand of support for the student arises. Schools have to ensure the career support (Korna-Opincane \& Katane, 2018; Kurochkina, et al., 2018; Reddan, 2015), a special attention devoting to educational and psychological support (Lamanauskas, 2013). Moreover, a successful career is predicted by several variables, for example, career commitment, career value, perceived organizational support etc. (Alzyoud Adel, 2017).

According to Jankevičius (2013), the main task of general education school is - to educate the growing generation for personal and social life. As the person's performed work and professional activity have the biggest importance both for his personal and social development, the target and the result of general education school should be a thoroughly mature (having acquired necessary amount of knowledge, abilities and skills, having developed interests, inclinations and talents, having formed value orientations and so on) personality, able to make conscious decisions, among which one of the most important would be professional self-determination, future career choice. Every subject teacher should also contribute to students' career competence education. According to Garnienè (2006), teachers should constantly learn and improve in career planning sphere, develop students' learning demand, professional orientation, inclination and intention selfdiagnostics and adequate self-evaluation abilities. Augustinienè (2007) emphasised the role of a teacher as a career consultant. Teacher, according to the researcher, performs "a communicator's" role, when he helps the student find the necessary information, ascertain its reliability, choose the most appropriate information presentation ways and forms, orally or in written form. In this way, a model of communication and collaboration in the community is revealed for the student, and the essence of it - competent information selection. The author notes that namely teachers create most of the learning situations, which help the student to cognise not only the surrounding world, but also to reveal and develop his interests, talents, personal features, learn to make decisions (Augustiniene, 2007). In other words, a very important function of a career consultant is ascribed to the teacher. Teachers should be career consultant partners. They can integrate various career education activities, related to a concrete learning topic, and this is more useful than to speak about irrelevant, unrelated things. Teachers can form teams, can work together with a career consultant or just be students' counsellors (Šedžiuvienè, Urbonienė, 2008). According to Career education 
programme (2014), subject teachers planning education content, plan topics into which career education is integrated. Career education programme refers to General Programmes of Lithuanian general education schools (2018). The teacher during the lessons, makes conditions for the students to develop career competencies.

The carried-out research conclusions and statistical data about students' career education situation (unemployment level, emigration extent and other) allow making an assumption, that students' professional information and career education in general education schools is not effective and sufficient. Looking at the conclusions made in the report of the State audit "How students' professional orientation is organised and carried out" (2014) and 2015-2016 academic year students' professional orientation (career education) observation report (2017) submitted data, it was noticed that career education nationwide has certain shortcomings and is a problematic education sphere. A big part of the students have never received services in their school or they were insufficient. Most of them, completing general education school, have not made their professional decision or their decisions later do not justify themselves. Because of that reason, it is necessary to improve career education system in general education schools, to form conditions for the students to better cognise themselves, their ambitions and possibilities, professions and the working world. This situation encourages to deeper analyse students' career education problems in general education schools and to reveal unused possibilities.

Research object: career education in general education schools. The research aim was to ascertain teachers' attitude to career education in general education schools. It was sought to analyse the organisation and carrying out of career education in general education schools, identifying the problems and revealing improvement possibilities.

\section{Research Methodology}

\section{General Characteristics}

The research was based on the attitude that career education is a systematic and purposeful process, by which it is helped the student to make a career choice and to acquire career competencies. In the research a survey strategy was applied. The research was of a pilot type. The research was carried out in Klaipeda city municipality general education schools in 2017.

\section{Research Sample}

The research participants were 100 general education school teachers. Out of them $97 \%$ of female and $3 \%$ of men. The youngest teacher, having participated in the research was 22 , the oldest63 years old, teacher age average -47 years $(S D=9.67)$. The smallest length of service was 1 year, the biggest -40 years, length of service average -23 years $(S D=10.4)$. Teachers' age and length of service characteristics are presented in table 1.

Table 1. Teachers' age and length of service characteristics $(\mathrm{N}=100)$

\begin{tabular}{cccc}
\hline Variable & Minimal meaning & Maximal meaning & Average \\
\hline Age & 22 & 63 & 47.2 \\
Length of service & 1 & 40 & 23 \\
\hline
\end{tabular}

Seeking to compare teachers' opinion differences according to the age, teachers were distributed into 3 age groups: up to 42 years $(N=33,33.3 \%), 43-53$ - year-old teachers $(N=35,35.5 \%)$, and teachers older than 54 years $(N=31,31.3 \%) .1$ teacher did not indicate his age. Also, the teachers were distributed into 3 groups according to the length of service: up to 18 years $(N=34,34.3 \%), 19$ 29 years $(N=31,31.3 \%)$, and 30 and more years $(N=34,34.3 \%)$ length of service having teachers. Distributing into groups, the requirement was taken into consideration (Kardelis, 2007) that the minimal case number in a group should not be less than 30 . The greater part of the teachers having 
participated in the research $(N=67,68.4 \%)$ were teachers-methodologists. About the third part of the respondents made teachers $(N=11,11.2 \%)$, senior teachers $(N=10,10.2 \%)$, and teachers-experts $(N=10$, $10.2 \%)$. Two teachers did not indicate their qualification category. The teachers were distributed into 2 qualification categories: teachers $(N=31,31.3 \%)$, and teachers-methodologists $(N=67,67.7 \%)$.

Teacher distribution according to the occupied position at school is presented in table 2 .

Table 2. Teacher distribution according to the occupied position at school $(\mathrm{N}=100)$.

\begin{tabular}{lll}
\hline \multicolumn{1}{c}{ Position } & $\boldsymbol{N}$ & $\%$ \\
\hline Subject teacher & 63 & 63 \\
Class teacher & 36 & 36 \\
Head master's assistant for & 16 & 16 \\
education & 3 & 3 \\
School psychologist & 1 & 1 \\
Social pedagogue & & \\
\hline
\end{tabular}

Most of all participating in the research were subject teachers (63\%), and class teachers (36\%). The least participating were school psychologists and social pedagogues (see Table 3).

During the research were revealed the respondents' relations with students' career education (see Table 3).

\section{Table 3. Teacher, having participated in the research, relations with students'} career education $(\mathrm{N}=100)$.

\begin{tabular}{lcc}
\hline \multicolumn{1}{c}{ Relations with students' career education } & N & $\%$ \\
\hline Carry out integrated career competence education during subject lessons & 52 & 52 \\
Carry out integrated career competence education during class hours & 40 & 40 \\
Carry out integrated career competence education during non-formal education activity & 14 & 14 \\
Work group member of school career education & 6 & 6 \\
Not related with students' career education & 17 & 17 \\
Leader, responsible for career education sphere & 7 & 7 \\
Specialist responsible for that sphere & 3 & 3 \\
\hline
\end{tabular}

More than half (52\%) of the teachers, having participated in the research, carried out integrated career competence education during subject lessons, a little less (40\%) - carried out integrated career competence education during class hours. A small part of the teachers, having participated in the research, were school leaders $(7 \%)$ or specialists $(3 \%)$ responsible for career education sphere.

The survey was carried out online. Using "Google forms" device, a questionnaire was presented to the teachers.

\section{Research Instrument and Procedure}

The questionnaire for general education school teachers comprised 15 closed-ended and openended type of questions. Taking into account the carried out theoretical analysis, the questions were formed, revealing teachers' attitude to their contribution carrying out career education activities in general education school. The questionnaire link for teachers was sent by e-mail to all Klaipeda city municipality general education schools ( 32 schools) with the request to spread it to all school teachers. The research was carried out following the research conducting ethical requirements. During 
the research, ethical principles were followed: benevolence, respect for person's dignity, rightness and the right to obtain exact information. Every research participant, without being forced, had the right to decide about the participation in the research. The respondents on their own accord agreed to participate in the research. They were informed about research aims, tasks, methods, the respondent's rights. Also, the respondents were assured of the obtained information confidentiality (nobody, except the researcher without the respondent's agreement could use his submitted information), and anonymity (the respondents did not have to write their name and surname).

\section{Data Analysis}

Descriptive statistics frequency calculation and average comparison procedure was applied. The evaluation of averages was presented, the most frequently appearing evaluation value, standard deviation, minimal and maximal evaluation value. Mann-Whitney criterion was used searching for the correlation between two variables, one of which is (dependent) variable measured by ranking scale, and another is (independent) variable - by nominal scale. Independent variable can have two meanings. Analysing the data, the most important is $p$ meaning and the rank averages of the answers. The bigger is the rank average, the bigger is the respondents' approval of this opinion and vice versa. The smaller is the ranking average, the respondents are less disposed to approve of the analysed opinion. Kruskal-Wallis criterion was applied searching for correlation between two variables, one of which is (dependent) variable measured by ranking scale, and another (independent) variable by nominal scale.

\section{Research Results}

During the research, it was sought to find out how teachers understood career education significance/meaning. A very big part of the teachers, having participated in the research, pointed out that career education was important and significant. The teachers, expressing their opinion about career education significance/meaning, indicated that career education was important (13 teachers: "career education is very important"; "career education meaning is important, if the carried out activities are planned, having continuation and clear guidelines"; "this is very important, because I would like to see my students successful in future"; "career education meaning is very important for students' development, self-cognition, self-career cognition"), necessary (6 teachers: "career education is necessary"; "it is necessary, especially for senior form students), significant (2 teachers: "this is a very significant education sphere"), useful (2 teachers: "a very useful thing"; "it is very useful for senior form students"), career education significance was great ( 8 teachers: "career education significance is great taking into consideration Lithuanian demographic situation and situation in the labour market"; "great, because it is very difficult for the students to choose their way of life), informed about professions (10 teachers: "helps the student to gather more information"; "this is information for students about very important questions for them related to their future profession"; "it is important to inform the students so that they know what profession they can choose, what profession supply is"; "it is interesting for the students to get acquainted with unknown professions"). Career education helped the young man to prepare for life (5 teachers: "very big, choosing the right direction determines the students' further life path"; "I think that career education is important, choosing further life path, career"; "the earlier students get acquainted with career, the wider will be students' outlook"), to choose profession (11 teachers: "introduces to professions, helps earlier to make a decision"; "career education is very important, because the earlier students get acquainted with various professions, the easier will be for them to choose an appropriate profession in future"; "to help suitably choose the speciality, to find out about studies"; "to give an opportunity to find out various sphere specialist work specificity, easier to choose profession in future", and plan career (8 teachers: "career education helps to cognise oneself as personality, and to choose a direction for future professional activity" " to educate young generation think about their future is perfect! It is necessary to teach students to cognise themselves as personality, to teach to apply knowledge about themselves choosing a further career path"; "I am for career education. This will give more possibilities for students in future, they will be able to plan the time, will better cognise themselves, 
will set their goals. The more we talk about this, the more benefit we will have; "helps the student to form self-consciousness about career choice"), facilitated preparation for future ( 7 teachers: "to facilitate students' preparation for future, to get acquainted with the aim of planned career; to encourage young people think about their future plans, to provide with information about choice possibilities. In progymnasium, further learning possibility review is very important"; "I think that students must know that all subjects they are learning at school will suit in a real life as well and, of course, in future career; "important and necessary. It is necessary to help students get acquainted with profession diversity and choice possibilities, help to plan learning and working activity") and developed their career competencies (3 teachers: "educate and form conditions for all students to develop their career competencies. Develop students' abilities to plan career"; "career education is a significant part of general education and vocational teaching, the educational influence of which remains very important for the learners throughout the life. Contemporary working world dynamics and learning possibility diversity raise plenty of requirements for a person in his career path. Career competencies are necessary for him, defined as attitude, knowledge, understanding and ability wholeness, on which it is based the personality himself and his career cognition, its planning, management and coordination with other his life aspects"). A few teachers expressed their opinion that career education organisation was problematic (10 teachers: "these activities are episodic"; "at this moment it is minimal"; " it has the meaning, when professionals of this sphere speak about career, but not teachers", "it is a necessary sphere, but it should be organised differently"; "in progymnasium (5-8 forms.) it is still not so important).

During the research, it was also inquired how teachers valued students' career education demand in general education schools. The biggest part of the teachers, having participated in the research, pointed out that there was a career education demand in general education schools. The majority of the teachers, having participated in the research, noted that there was career education demand in general education schools: career education is very necessary ( 22 teachers: " a very important thing"; I think it is necessary, especially for these and the coming generations"; "I think that this is one of the main ways to show that given subjects are not only theory, which is not needed in life"; "a lot of students do not have who to consult, a qualified help is necessary at school"; " in the gymnasium, it is a very necessary sphere, a lot ask, look for help, specialists able to help the student are necessary, to attend exhibitions, to get acquainted with professions, activities"), there is a demand (9 teachers: "there is a demand. Events, lessons, related to career education always get positive evaluation"; "there is a demand, students are interested, willingly participate in activities"), it is important ( 8 teachers: "it is an important task, students get interested, it may be easier to choose later"; "I think that career education is very important and significant for students"; "it is important to help cognise oneself, to evaluate in reality one's abilities, to teach to plan"; "in every age period it is important"), it is necessary (6 teachers: I think that career education has to be. Sincerely I envy nowadays students, that the teachers take them to show various workplaces - earlier this did not use to happen, and nobody would use to tell about this. Where has the student to find that out from, if not from school?"), good (8 teachers), positive (12 teachers), urgent ( 2 teachers) and useful ( 1 teacher). Four teachers indicated that the demand depended on the students' age ("in progymnasium - minimal demand. The decisions make parents. Accent to education and information"; "in progymnasium we step only elementary steps towards career education. Teachers as much as possible integrate into subject lessons"; "career education should be much more accentuated and developed in lower secondary school (9-10 forms) and in gymnasiums than in progymnasiums or primary schools"; "programme is necessary, in my opinion, from $7-8$ grades"). There were opinions that career education was problematic: there is no appropriate career education organisation (5 teachers: "I think career education is very important, only there is no its appropriate organisation. All organisational questions lie on teachers' shoulders. City department of Education employees should make a list (with contacts) of enterprises, which agree to accept students"; "negatively, because there are no practical conditions "to try on various professions, and oral conversations - are only a waste of time"; "in my opinion, it is more like "paper-bureaucratic" demand at the moment, because it is not clear, how it has to be performedactivities and their planning are left for the teacher/class teacher. An exhaustive programme should be prepared, conforming to every age period, foreseen devices to implement it. Maybe then, the meaning of this programme will be more understandable for the students as well. It should not be 
one more "tick", that we have to put, but continual, directing and orienting a young man towards future career. Of course, live examples inspire, encourage, therefore, it would be pleasant to have people at school, who share their achievements, and a recipe of success with the young man. This should not be left for a class teacher competence, but on the contrary - carried out state-wide"), there is a lack of career education programmes ( 3 teachers: " 8 from 10 most popular professions in 2016 did not exist 10 years ago. Most of the professions, which today's first-formers will need, still do not exist. It is predicted that our children during their life will change at least some (between 1 to 19) workplaces, and for that they will need quite a lot of courage, self-reliance and creativity. Thus, only knowledge and academic student's achievement is not enough. Today's school aim is - to bring up creative, motivated, public-spirited, having value in backbone, fostering cultural values and all-round literate children"; "I think, career education is necessary, only one needs very thoughtful programmes, what age students to teach") and career education essence is not understood (2 teachers: "still it is not understood its essence, though it is worked, a slow procedure and improvement"; "in primary and general education stages, it is fragmentary education").

So, although some teachers indicated that the demand depended on students' age, and a few stated that career education organisation was problematic, in the opinion of teachers, having participated in the biggest part of the research, there is a career education demand in general education schools, this sphere is important and urgent.

During the research, it was sought to ascertain how general education teachers valued the factors, helping carry out career education at school. The evaluation smallest and biggest values, evaluation averages and standard deviations were calculated (see table 4).

Table 4. Factors, helping carry out career education at school $(\mathrm{N}=100)$.

\begin{tabular}{|c|c|c|c|c|}
\hline Factors & 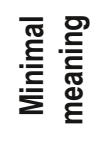 & 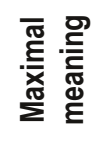 & 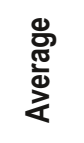 & 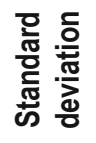 \\
\hline Positive school leaders' attitude in respect to career services & 1.00 & 7.00 & 5.87 & 1.39 \\
\hline Teacher responsible for career education activeness and initiative & 2.00 & 7.00 & 5.79 & 1.35 \\
\hline A full-time career specialist position establishment at school & 1.00 & 7.00 & 5.64 & 1.91 \\
\hline Consistent activity planning & 1.00 & 7.00 & 5.60 & 1.45 \\
\hline Students' initiative and interest in their future & 2.00 & 7.00 & 5.60 & 1.55 \\
\hline Active collaboration with other institutions, helping carry out career services & 2.00 & 7.00 & 5.55 & 1.51 \\
\hline Close collaboration with parents on career education questions & 1.00 & 7.00 & 5.38 & 1.37 \\
\hline All school teachers' responsibility and contribution to students' career education & 2.00 & 7.00 & 5.47 & 1.45 \\
\hline Effective career service management and administration & 2.00 & 7.00 & 5.44 & 1.25 \\
\hline Active school Career Education work group & 1.00 & 7.00 & 5.44 & 1.51 \\
\hline Purposeful teacher trainings, qualification raise in career education sphere & 1.00 & 7.00 & 4.95 & 1.76 \\
\hline
\end{tabular}

Carrying out career education activities, in teachers' opinion, the biggest significance had these factors: positive school leaders' attitude in respect to career services $(\mathrm{x}=5.87, S D=1.39)$, and teacher, responsible for career education, activeness and initiative $(\mathrm{x}=5.79, S D=1.35)$. The least effective were - purposeful teacher trainings, qualification raise in career education sphere ( $\mathrm{x}=4.94, S D=1.35)$. So, the most significant factors, helping carry out career education at school were positive school leaders' attitude in respect to career services, and teacher responsible for career education activeness and initiative.

Having applied Kruskal-Wallis criterion, statistically significant evaluation differences of one factor helping carry out career education at school - close collaboration with parents on career education questions - were ascertained according to the teachers' age $\left(\chi^{2}=6.777, d f=2, p=.034\right)$ : 
43 - 53 year old teachers (average rank - 59.07), higher than teachers up to 42 years old (average rank -46.86), and senior than 54 years old (average rank -41.81) evaluated this factor as effective, carrying out career education at school. Having applied Mann-Whitney U criterion, statistically significant two factor, helping carry out career education at school, differences were ascertained according to the type of school. Gymnasium teachers (average rank - 56.05), higher than progymnasium teachers (average rank - 44.55) helping carry out career education at school evaluated a positive school leaders' attitude regarding career services, as a factor helping carry out career education at school (Mann-Whitney $U=790.500, p=.042$ ). Also, gymnasium teachers (average rank - 56.59) higher than progymnasium teachers (average rank - 43.21) evaluated a full-time career specialist position establishment at school - as a factor, helping carry out career education at school (Mann-Whitney $U=2636.000, p=.014)$. Having applied Mann-Whitney $U$ criterion, statistically significant two factor, helping carry out career education at school, differences were established according to the teachers' qualification category. Teachers-methodologists (average rank - 52.36) higher than the other teachers (average rank - 40.02) evaluated active collaboration with other institutions, helping carry out services, as a factor, helping carry out career education at school (Mann-Whitney $U=735.500$, $p=.037$ ). Also, teachers-methodologists (average rank -54.01 ) higher than other teachers (average rank - 36.38) evaluated close collaboration with parents on career education questions, as a factor, helping carry out career education at school (Mann-Whitney $U=626.500, p=.003$ ).

Thus, having ascertained one factor, helping carry out career education at school - close collaboration with parents on career education questions - statistically significant evaluation differences according to the teachers' age, one can see that 43-53-year old teachers considered this factor more effective than teachers up to 42 years old and older than 54 years old. According to the type of school, in which the teacher having participated in the research works, the effectiveness evaluations of two factors helping carry out career education at school, statistically significantly differed. Gymnasium teachers higher than progymnasium teachers evaluated the effectiveness of a positive school leaders' attitude regarding career services and full-time career specialist position establishment, carrying out career education at school. According to the teachers' qualification category, statistically significantly were notable two factor significance evaluation differences. Teachers methodologists considered active collaboration with other institutions helping carry out career services and close collaboration with parents on career education questions as factors more significant helping carry out career education at school than other teachers.

During the research it was sought to ascertain, how general education school teachers valued the factors, encouraging the students be interested and plan their career. It was calculated the smallest and the biggest evaluation values, evaluation averages and standard deviations (see table 5).

Table 5. Factors, encouraging students to be interested and plan their career $(\mathrm{N}=100)$.

\begin{tabular}{|c|c|c|c|c|}
\hline Factors & 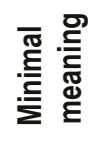 & 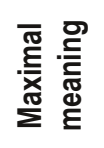 & 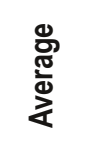 & 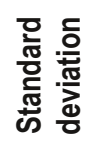 \\
\hline Parent and other close people help & 2.00 & 7.00 & 6.36 & 1.02 \\
\hline Attractive, compatible with the students' age, career education forms & 2.00 & 7.00 & 6.23 & 1.16 \\
\hline Career specialist's professionality & 2.00 & 7.00 & 6.21 & 1.10 \\
\hline Career specialist's personal features & 2.00 & 7,00 & 6.17 & 1.04 \\
\hline Personal students' features & 2.00 & 7.00 & 6.17 & 1.08 \\
\hline Students' abilities and expressed talents & 3.00 & 7.00 & 6.16 & 1.08 \\
\hline Information about career services dissemination & 2.00 & 7.00 & 6.16 & 1.08 \\
\hline All teachers' role and attitude to career education importance & 2.00 & 7.00 & 6.11 & 1.06 \\
\hline Social environment of the students & 2.00 & 7.00 & 6.06 & 1.17 \\
\hline
\end{tabular}




\begin{tabular}{|c|c|c|c|c|}
\hline Factors & 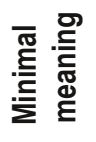 & 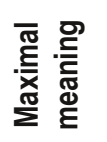 & 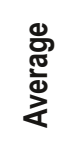 & 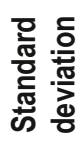 \\
\hline Appropriately chosen teaching methods & 2.00 & 7.00 & 6.04 & 1.16 \\
\hline Students' work or voluntariness experience & 2.00 & 7.00 & 6.00 & 1.23 \\
\hline Students' responsible attitude to all teaching process & 2.00 & 7.00 & 5.95 & 1.31 \\
\hline Early primary career education & 1.00 & 7.00 & 5.22 & 1.76 \\
\hline
\end{tabular}

Teachers pointed out that the factors mostly encouraging students be interested and plan their career were parents' and close people influence $(\mathrm{x}=6.36, S D=1.02)$, attractive, compatible with the students' age career education activity forms $(\mathrm{x}=6.23, S D=1.16)$, and career specialist's professionality $(\mathrm{x}=6.21, S D=1.1)$. Early primary career education $(\mathrm{x}=5.22, S D=1.16)$ and students' responsible attitude to all teaching process $(\mathrm{x}=5.95, S D=1.31)$ were evaluated as the least encouraging factors. So, looking at teachers' evaluations one can see that parents' and other close people influence, attractive, compatible with the students' age career education activities, and career specialist's professionality encouraged students to be interested and plan their career most of all.

Statistically significant evaluation differences of two factors encouraging students to be interested and plan their career were ascertained according to the type of school. Gymnasium teachers (average rank - 57.60) higher than progymnasium teachers (average rank - 45.20) evaluated career specialist's personal features, as a factor, encouraging students to be interested and plan their career (Mann-Whitney $U=2892.500, p=.026$ ). Also, gymnasium teachers (average rank - 58.44) higher than progymnasium teachers (average rank -43.90) evaluated all teachers' role and attitude to career education importance, as a factor, encouraging students to be interested and plan their career (MannWhitney $U=2766.000, p=.009$ ).

Also, statistically significant evaluation differences of three factors, encouraging students to be interested and plan their career were established according to the teachers' age (see Table 6).

Table 6. Certain factor, encouraging students to be interested and plan their career, evaluation differences according to the teachers' age $(\mathbf{N}=100)$.

\begin{tabular}{|c|c|c|c|c|c|c|}
\hline \multirow{2}{*}{ Factors } & \multicolumn{3}{|c|}{ Average ranks } & \multicolumn{3}{|c|}{$\begin{array}{l}\text { Kruskal-Wallis } \\
\text { criterion }\end{array}$} \\
\hline & $\begin{array}{l}\text { Up to } 42 \\
\text { years }\end{array}$ & $\begin{array}{c}43-53 \\
\text { years } \\
\text { old }\end{array}$ & $\begin{array}{c}\text { Older than } 54 \\
\text { years }\end{array}$ & $x^{2}$ & $d f$ & $p$ \\
\hline Personal students' features & 61.11 & 45.54 & 41.48 & 10.182 & 2 & .006 \\
\hline Appropriately chosen teaching methods & 61.97 & 41.79 & 44.63 & 11.092 & 2 & .004 \\
\hline $\begin{array}{l}\text { All teachers' role and attitude to career education } \\
\text { importance }\end{array}$ & 58.74 & 40.76 & 47.40 & 7.932 & 2 & .019 \\
\hline
\end{tabular}

In the table one can see that younger teachers, whose age was up to 42 years, higher than $43-53$ and older than 54 year old teachers evaluated the factors, encouraging students to be interested and plan their career: personal students' features (up to 42 year old teachers' average rank was -61.11 , 43-53 year old -45.354 , and older than 54 years -41.48 ), appropriately chosen teaching methods (average ranks respectively $-61.97,41.79,44.63$ ), and all teachers' role and attitude to career education importance (average ranks respectively - 58.74, 40.76, 47.40).

Additionally, statistically significant evaluation differences of three factors, encouraging students to be interested and plan their career, were ascertained according to the teachers' qualification category (see Table 7). 
Baltic Journal of Career Education and Management
Table 7. https://doi.org/10.33225/bjcem/18.6.15

in factor, encouraging students to be interested and plan their career, evaluation differences according to the teachers' qualification category $(\mathrm{N}=100)$.

\begin{tabular}{lcccc}
\hline \multirow{2}{*}{ Factors } & \multicolumn{2}{c}{ Average ranks } & \multicolumn{2}{c}{ Mann-Whitney criterion } \\
\cline { 2 - 5 } & $\begin{array}{c}\text { Teachers } \\
\text { methodologists }\end{array}$ & $\begin{array}{c}\text { Other } \\
\text { teachers }\end{array}$ & Mann-Whitney $\boldsymbol{U}$ & $\boldsymbol{p}$ \\
\hline Career specialist's professionality & 52.99 & 40.10 & 738.000 & .021 \\
$\begin{array}{l}\text { Career specialist's personal features } \\
\begin{array}{l}\text { Information about career services } \\
\text { dissemination }\end{array}\end{array}$ & 53.12 & 39.80 & 729.000 & .020 \\
\hline
\end{tabular}

It can be seen from the table, that teachers methodologists higher than other teachers evaluated the factors encouraging students to be interested and plan their career: career specialist's professionality (teacher methodologists' average rank - 52.99, the other teachers' average rank - 40.10), career specialist's personal features (average ranks respectively - 53.12 and 39.80), and information about career services dissemination (average ranks respectively - 52.41 and 39.47). Thus, teachers - methodologists higher than other teachers evaluated these factors as encouraging students to be interested and plan their career: career specialist's professionality, career specialist's personal features and information about career services dissemination.

During the research, it was sought to find out which students' career competencies the teachers considered important and to be developed at school (Table 8).

Table 8. Career competencies that are important and need to be developed at school $(\mathrm{N}=100)$.

\begin{tabular}{|c|c|c|c|c|}
\hline Competencies & 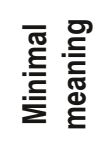 & 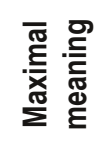 & 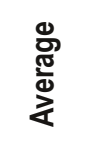 & 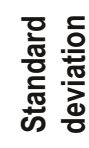 \\
\hline Cognise and accept oneself, trust oneself & 2.00 & 7.00 & 6.59 & 0.97 \\
\hline Find and effectively use career information & 2.00 & 7.00 & 6.39 & 0.95 \\
\hline Cognise one's personality peculiarities and their relations with career & 2.00 & 7.00 & 6.38 & 1.06 \\
\hline Cognise learning possibilities & 2.00 & 7.00 & 6.34 & 0.94 \\
\hline Cognise working world possibilities, variety and change & 2.00 & 7.00 & 6.31 & 0.94 \\
\hline Raise one's learning aims, reflect and evaluate their achievements & 1.00 & 7.00 & 6.23 & 1.13 \\
\hline Raise life and career aims & 1.00 & 7.00 & 6.17 & 1.25 \\
\hline Cognise social environment, social roles and their influence on personal career & 3.00 & 7.00 & 6.16 & 1.05 \\
\hline Develop and apply important to career general competencies & 1.00 & 7.00 & 6.01 & 1.24 \\
\hline Create career vision & 1.00 & 7.00 & 5.96 & 1.31 \\
\hline Coordinate career with other life spheres & 1.00 & 7.00 & 5.92 & 1.34 \\
\hline Cognise and understand economy changes & 1.00 & 7.00 & 5.90 & 1.15 \\
\hline Manage personal finances & 1.00 & 7.00 & 5.80 & 1.23 \\
\hline Make career decisions & 1.00 & 7.00 & 5.80 & 1.54 \\
\hline Purposefully search for practice, work or create one's own business & 1.00 & 7.00 & 5.78 & 1.41 \\
\hline Successfully move to the new career environment and settle in it & 1.00 & 7.00 & 5.75 & 1.31 \\
\hline Make career plan & 1.00 & 7.00 & 5.71 & 1.36 \\
\hline
\end{tabular}


In teachers' opinion, the most important and necessary to be developed students' career competencies were: cognise oneself and accept oneself, trust in oneself $(\mathrm{x}=6.59, S D=0.97)$, find and effectively use career information $(\mathrm{x}=6.38, S D=0.94)$, and cognise learning possibilities $(\mathrm{x}=6.34$, $S D=0.94)$. The categories: make a career plan $(\mathrm{x}=5.71, S D=1.36)$, accept career decisions $(\mathrm{x}=5.80$, $S D=1.54)$, and manage personal finances $(\mathrm{x}=5.80, S D=1.23)$ were evaluated as less important and necessary to be developed.

Statistically significant evaluation differences of the students' competencies important and necessary to be developed at school were ascertained, according to the type of school (see Table 9).

Table 9. Career competence evaluation differences according to the type of school $(\mathrm{N}=100)$.

\begin{tabular}{lcccc}
\hline \multicolumn{1}{c}{ Competencies } & \multicolumn{2}{c}{ Average ranks } & Mann-Whitney criterion \\
\cline { 2 - 5 } & $\begin{array}{c}\text { Gymnasium } \\
\text { teachers }\end{array}$ & $\begin{array}{c}\text { Progymnasium } \\
\text { teachers }\end{array}$ & U \\
\hline Create career vision & 60.09 & 44.72 & 762.000 & .007 \\
$\begin{array}{l}\text { Raise life and career goals } \\
\text { Make career decisions }\end{array}$ & 55.65 & 44.75 & 803.500 & .043 \\
$\begin{array}{l}\text { Make a career plan } \\
\begin{array}{l}\text { Purposefully search for practice, work or } \\
\text { create one's own business }\end{array}\end{array}$ & 61.50 & 43.98 & 714.000 & .002 \\
\hline
\end{tabular}

In the table one can see that gymnasium teachers higher than progymnasium teachers evaluated these students' career competencies, which were important and necessary to develop at school: create career vision (gymnasium teachers' average rank -60.09, progymnasium -44.72), raise life and career goals (respectively - 55.56 and 44.75), make career decisions, (respectively - 61.50 and 43.98), make a career plan (respectively 63.46 and 42.96), and purposefully search for practice, work or create one's own business (respectively 58.79 and 45.50).

According to the teachers' age, the evaluation of one students' career competence cognise social environment, social roles and their influence on personal career $\left(\chi^{2}=6.462, d f=2, p=.039\right)$ statistically significantly differed: teachers up to 42 years old (average rank -58.65 ) higher than senior than 54 years old (average rank - 50.90) and 43-53 year-old teachers (average rank - 44.11) evaluated this competence as very important and necessary to be developed at school.

Almost two thirds of the teachers indicated that information about career services was presented in the information stand (66.7\%), and in the school's internet page (64.6\%), one fourth of the teachers $(26.3 \%)$ - on the career specialist's door. 3 teachers additionally pointed out that the information about career services was provided by career specialist ("during class hours career specialist introduces himself personally and informs about activity", "a person responsible for this organises different activities", "a specialist visits classes with information"). 2 teachers noted that information was disseminated through class teachers ("through electronic register in the class teachers' group", "through class teachers"). A few teachers pointed out that information was provided through various activities ("through events, integrating into subject content, class hours, organising trips, excursions"), 1 teacher- in subject rooms (in maths, economics, geography rooms I saw profession possibilities).

During the research, it was sought to find out teachers' opinions about career competence development integration (Table 10). 


\begin{tabular}{|c|c|c|c|c|c|}
\hline Statements & 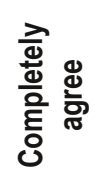 & 浐 & 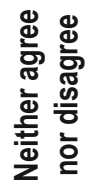 & 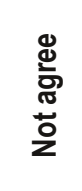 & 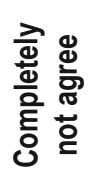 \\
\hline Career education must be integrated into all subjects & 15.2 & 36.4 & 37.4 & 8.1 & 3.0 \\
\hline Career education can be integrated only into some subjects & 7.1 & 45.5 & 23.2 & 15.2 & 8.1 \\
\hline $\begin{array}{l}\text { Career education can be integrated only into non-formal students' } \\
\text { education }\end{array}$ & 6.1 & 11.1 & 22.2 & 44.4 & 16.2 \\
\hline Career education can be integrated only into class hours & 3.0 & 13.1 & 21.2 & 47.5 & 14.1 \\
\hline $\begin{array}{l}\text { Career education has to be implemented throughout all education } \\
\text { process }\end{array}$ & 33.3 & 45.5 & 13.1 & 7.1 & 1.0 \\
\hline $\begin{array}{l}\text { Some subject topics are closely related to career education } \\
\text { programme and naturally coincide with their content }\end{array}$ & 27.3 & 58.6 & 8.1 & 5.1 & 1.0 \\
\hline $\begin{array}{l}\text { Career education has to be implemented only through purposefully } \\
\text { foreseen activities }\end{array}$ & 7.1 & 35.4 & 34.3 & 20.2 & 3.0 \\
\hline $\begin{array}{l}\text { Integration strengthens subject learning, contributes to deeper } \\
\text { subject competence development }\end{array}$ & 17.2 & 52.5 & 23.2 & 5.1 & 2.0 \\
\hline $\begin{array}{l}\text { Integration emphasises subject application in real life possibilities, } \\
\text { encourages reflective learning }\end{array}$ & 20.2 & 48.5 & 25.3 & 2.0 & 1.0 \\
\hline Integration strengthens students' motivation to learn consciously & 19.2 & 49.5 & 28.3 & 2.0 & 1.0 \\
\hline $\begin{array}{l}\text { Subject programmes are overloaded with various integrated } \\
\text { programmes, which have to be included into subject content }\end{array}$ & 30.3 & 32.3 & 27.3 & 9.1 & 1.0 \\
\hline Integration is not effective, because it is performed only officially & 12.1 & 22.2 & 39.4 & 22.2 & 4.0 \\
\hline $\begin{array}{l}\text { During subject lessons, it is important to master subject knowledge } \\
\text { and to properly prepare for knowledge evaluation, therefore } \\
\text { integration only hinders }\end{array}$ & 7.1 & 11.1 & 40.4 & 30.3 & 10.1 \\
\hline $\begin{array}{l}\text { Subject teacher does not have the necessary preparation for } \\
\text { students' career education }\end{array}$ & 11.1 & 30.3 & 36.4 & 18.2 & 4.0 \\
\hline $\begin{array}{l}\text { Subject teacher has no support how to develop students' } \\
\text { competencies during the lessons }\end{array}$ & 12.1 & 28.3 & 34.3 & 18.2 & 7.1 \\
\hline $\begin{array}{l}\text { There is short of time for career competence development in the } \\
\text { lessons }\end{array}$ & 16.2 & 41.4 & 30.3 & 9.1 & 3.0 \\
\hline
\end{tabular}

In the table one can see, that the bigger part of the teachers approved of the statements related to career education integration: certain subject topics are closely related to career education programme and naturally coincide with their content (completely agree $-27.3 \%$, agree $-58.6 \%$ ), career education has to be implemented through all education process (completely agree - $33.3 \%$, agree $-45.5 \%$ ), integration strengthens subject learning, contributes to deeper subject competence education (completely agree $-17.2 \%$, agree $-52.5 \%$ ), integration emphasises subject application in real life possibilities, encourages reflective learning (completely agree $-20.2 \%$, agree $-48.5 \%$ ), and integration strengthens students' motivation to learn consciously (completely agree $-19.2 \%$, agree $-49.5 \%$ ). A small part of the teachers approved of the statements related to career education integration: career education can be integrated only to class hours (completely agree - $3 \%$, agree $13.1 \%$ ), career education can be integrated only to non-formal education of children (completely agree $-6.1 \%$, agree $-11.1 \%$ ), and during subject lessons it is important to master subject knowledge and appropriately prepare for knowledge evaluation, therefore integration only hinders (completely agree $-7.1 \%$, agree- $11.1 \%$ ). 
In the research it was analysed how teachers valued career education effectiveness in general education schools. Most of the teachers, having participated in the research, positively valued students' career education in general education school. 71 teacher pointed out that they valued students' career education positively: 23 teachers valued positively ("quite a lot is done, it is going in the right direction"; I think that it is perfect that students know that they can talk things over, know who to ask help for, that a professional can give advice, help to be interested, direct"; "in the progymnasium, career education helps senior form students raise learning targets and to seek chosen speciality"; "it is difficult to say exactly, but the benefit really is"). 16 teachers valued this sphere good ("a good result, students get acquainted with their personal features, with social environment, perceive their career as a long-term process"; "thanks to career specialist, I value good"). 14 teachers - average ("average, students are at a loss choosing future profession"; average, I think, for certain activities there is short of time, however, it is put a lot of efforts and energy, also, it is important, that extra work was paid for the teachers"; "still there is where to improve"). 15 teachers valued satisfactory (satisfactory I think, that career education results would be much better, if there was a career education specialist at school"; "6 points from 10"). 1 teacher in each pointed out that they valued perfect, excellent and career education was necessary. 6 teachers indicated that career education was problematic, because it was allotted very little time ( 2 teachers: "the results are not bad, however, in my opinion, it is allotted not much time during the lessons for career education at school. Teaching content is complicated and for integration with other subjects just there are no possibilities"; "it has to be devoted much more attention and time for this"). 2 teachers thought that there was lack of consistency ("in progymnasiums -fragmentary"; "though students get certain information, one would like to see a long-term plan or guidelines. This should be a constant process, however clear for both students and teachers"). 2 teachers stated that there was lack of effectiveness ("the professional orientation system up to now was and is not sufficiently effective"; "I think that during the project, when prepared career education specialists worked and organised all the process, the activities were more effective, the motivation was bigger). 4 teachers valued students' career education in general education schools negatively ("officially corresponding to minimal requirements. Practically lamentable"; "is not effective"). 6 teachers wrote that they did not have opinion about that question.

27 teachers pointed out that career specialist at school would better guarantee qualitative career education services. 12 teachers just wrote "career specialist"; "career education specialist's position"; "it would be most effective and useful if career specialist worked at school". 8 teachers specified "career specialist's full position"; "career specialist. In order career education went qualitatively, a separate person is necessary, working in that sphere"; "career specialist, but only if he gave career lessons". 7 teachers indicated that "properly prepared specialist"; "prepared career specialists"; "a good career specialist". 22 teachers pointed out that collaboration would guarantee qualitative career education conditions: 12 teachers identified that collaboration among school community members ("everybody's common and concentrated work in that direction"; "appointed and prepared specialists for that, collaborating with class teachers and parents"; "big integrity of parents, teachers and an interest of a student himself"; "benevolent collaboration among themselves"). 5 teachers in each noted that collaboration with other organisations ("also, it is important to show interest from outside and not only from the school's inside."; "help from municipality, centralised agreements with various institutions about volunteer acceptance, about "shadowing", that the school was not left alone to search for contacts"; "bigger business representative involvement in a young man 's future") and among specialists ("for that purpose appointed and prepared specialists, collaborating with class teachers and parents"). 11 teachers identified that seeking that the career education services functioned qualitatively, clear students' career education strategy was necessary at school ("clear education institution strategy implementing career education programme"; "programme integration into formal and non-formal education is insufficient and remains only episodic"; "all school common agreements and common goals"; "various programme conformity"). This, that more diverse career education activities would assure qualitative career education services, pointed out 12 teachers, i.e. meetings with different profession people (5 teachers: "more "live examples", different profession people, who could in reality introduce with career, all plusses and minuses. When the students see what the real work is and what is every day, they themselves will start more seriously value this thing"; "meetings with various profession specialists, opportunity to be assistants in the working 
place"; "successful young man's arrival at gymnasium to share one's experience and motivation for science and career"), practical activities (4 teachers) and visits to enterprises (3 teachers: "trips to various organisations, workplaces"; "students'trips to concrete objects (professional centres)"). A few teachers indicated that raising teacher qualification ( 7 teachers: "more information would be necessary about this programme integration into separate subject programmes"; teacher and student support specialist qualification raise on career education subjects"; "appropriate preparation of the teachers themselves, extra time devoted to namely that subject"; "innovative teachings for various subject teachers") and prepared career education material (2 teachers: "not the instruction, but a real content created and applied for using during the lessons would assure more, that it is necessary to integrate into the subject content. If the teacher did not have to create the content (usually he has to do it at the expense of his leisure time, because the time is not allotted for this)"; "more successful activity scenarios, activity plans, practical advice") would assure qualitative career education services at school.

\section{Conclusions}

School importance in the professional choice process plays a very great role. The main career education aim in general education school is to form conditions for the students to cognise their personal features and abilities, to provide them with information about professions and working world and to encourage them to search and find the equivalent between their personality and the corresponding profession. School and the provided career services in it have to help the students make a rational professional decision, which would satisfy a person and society's demands.

The research results revealed that education process is very intensive, there is a lack of time for carrying out career education activities, there is lack of consistency, financing, not in all schools career education programme is prepared, there is no effectiveness, there is not enough of career education programmes, methodological devices, there is no all school community involvement into the career education organisation and social partner help for career education implementation outside the school. The research results show that carrying out career education activity is problematic also due to this, that there is no established full-time career specialist's position in general education school at a national level. Only a small part of career specialists at school work full time, the others have a smaller part of it, or a few hours are appointed from the school education plan for carrying out career education activities. So, one can make a conclusion that career education in general education schools is not properly organised.

Conclusions are applied only generalising the opinion of teachers and career specialists working in Klaipeda city general education schools, and not applied evaluating other city teacher and career specialist attitudes to career education problems and possibilities in general education schools.

\section{Literature}

2015-2016 m. m. mokiniu profesinio orientavimo (ugdymo karjerai) stebésenos ataskaita [2015-2016 m. monitoring of career guidance (career development) of learners]. (2017). Vilnius: Lietuvos mokiniu neformaliojo švietimo centras.

Alzyoud Adel, A. Y. (2017). The predictors of career success. International Review of Management and Marketing, 7(2), 22-26.

Augustiniené, A. (2007. The possibilities of students'career decision-making skills development at secondary school: Summary of doctoral dissertation: social sciences, educational science. Kaunas: Kauno technologijos universitetas.

Bendrosios programos [General Programs]. (2018) Retrieved from https://www.smm.lt/web/lt/smm svietimas/svietimas-vidurinis-ugdymas.

Chetana, N., \& Das Mohapatra, A. K. (2017). Career planning and career management as antecedents of career development: A study. Asian Journal of Management, 8(3), 614-618.

Garniene, D. (2006). Model of career education at general education school: Parameters and realisation principles: summary of the doctoral dissertation: social sciences, education. Kaunas: Vytauto Didžiojo universitetas. 
Jankevičius, S. (2013). Bendrojo ir ikiprofesinio ugdymo teorijos ir praktikos paradigmos [Paradigms of general and pre-vocational education theories and practices]. Vilnius: Lietuvos edukologijos universitetas.

Kaip organizuojamas ir vykdomas mokiniu profesinis orientavimas. Valstybinio audito ataskaita [How vocational guidance for students is organized and implemented. Public audit report]. (2014). Vilnius: Lietuvos Respublikos valstybès kontrolè.

Korna-Opincane, E., \& Katane, I. (2018). Topicality of career guidance at schools for promoting of students' professional self-determination. Research for Rural Development, 2, 252-258. doi: 10.22616/ $\operatorname{rrd} .24 .2018 .080$.

Kurochkina, L. V., Konstantinova, V. V., Arzamastseva, N. G., Basova, L. V., Trubyanova, I. V., \& Rybakov, A. V. (2018). Training of students for supervisory support of schoolchildren in professional self-determination. In Proceedings of SOCIOINT 2018- 5th International Conference on Education, Social Sciences and Humanities, 2-4 July 2018 (pp. 329-333). Dubai, U.A.E.

Lamanauskas, V. (2013). The importance of psychological teachers' preparation for educational activity. Psychological Thought, 6 (2), 169-172, doi:10.5964/psyct.v6i2.91.

Pukelis, K. (2003). Karjeros projektavimo gebèjimai žinių visuomenėje: nauji iššūkiai profesiniam konsultavimui ir karjeros planavimui [Career designing skills in the knowledge society: new challenges for vocational counselling and career planing] Profesinis rengimas: tyrimai ir realijos / Vocational Training: Research and Realities, 6, 66-75.

Pukelis, K., \& Garnienè, D. (2003). Moksleiviu ugdymas karjerai: padèties analizè ir perspektyvos bendrojo lavinimo mokykloje [Students career education: Situation analysis and prospects for general education]. Kaunas: Vytauto Didžiojo universitetas. Retrieved from: http://etalpykla.lituanistikadb.lt/fedora/objects/ LT-LDB-0001:J.04 2003 1377784905520/datastreams/DS.002.0.01.ARTIC/content

Reddan, G. (2015). Enhancing students' self-efficacy in making positive career decisions. Asia-Pacific Journal of Cooperative Education, 16(4), 291-300.

Surgèlienė, J., \& Bankauskienė, N. (2014). Ugdymo karjerai procese veikiantys subjektai istoriniame kontekste [Subjects in the career education process in the historical context]. Kaunas: Kauno technologijos universitetas. Retrieved from: file:///C:/Users/PPT/AppData/Local/Temp/8-6-1-PB.pdf.

Šedžiuvienė N., \& Urbonienė, L. (2008). Profesinis orientavimas aukštojoje mokykloje: veiklos principai ir kryptys [Professional counselling in higher schools: Principles and directions of activities]. Pedagogy Studies (Pedagogika), 90, 18-25.

Ugdymo karjerai programa [Career Education Program] (2014). Retrieved from https://e-seimas.lrs.lt/portal/ legalAct/lt/TAD/11018e70d00711e39b2ab5bbcc4f49fb.

\begin{tabular}{cl}
\hline Kristina Gelažauskienė & $\begin{array}{l}\text { MSc., Career Education Specialist, Klaipèda Pedagogical Psychological Service, 41-1 } \\
\text { Debrecen Street, LT-94164 Klaipèda, Lithuania. } \\
\text { E-mail: kgelazauskiene@gmail.com } \\
\text { Website: http://www.klaipedosppt.It/ }\end{array}$ \\
\hline Dalia Augienė & $\begin{array}{l}\text { Ph.D., Senior Researcher at the University of Siauliai, Institute of Education, P. } \\
\text { Visinskio Street 25, LT-76351 Siauliai, Lithuania. } \\
\text { E-mail: augiene@gmail.com } \\
\text { Website: http://www.su.lt }\end{array}$ \\
\hline Vincentas Lamanauskas & PhD, Professor, University of Šiauliai, Institute of Education, P. Visinskio Street 25- \\
& 119, LT-76351 Siauliai, Lithuania. \\
& E-mail: v.lamanauskas@ef.su.lt \\
Website: http://www.lamanauskas.puslapiai.It/ & https://www.researchgate.net/profile/Vincentas_Lamanauskas \\
\hline
\end{tabular}

